\title{
Semantic Connotation of Hadith and the Emergence of Arabic Schools of Grammar
}

\author{
Dr. S. A. Shittu \\ Dr I. A. S. Adebolu
}

Department of Arabic and Islamic Studies

University of Ibadan, Ibadan, Nigeria

doi: 10.19044/esj.2016.v12n20p186 URL:http://dx.doi.org/10.19044/esj.2016.v12n20p186

\begin{abstract}
Scholars focused the contributions of the Qur'ann to the evolution of Arabic Grammar, but few of them focused on the effect of prophetic tradition on the area. This paper, therefore, focuses on semantic connotation of prophetic traditions: "Guide your brother, he has gone astray" and "Divergent opinion of my followers is a blessing" These sayings of the prophet led to the evolution of Arabic grammatical studies and the establishment of its schools that enriched Arabic grammar. It opens with the grammarians' contribution to the development of Arabic grammar such as Abul-Aswad Addu'alī (d.69 A.H), Seyyid 'Ali b. Abī Talib, al-Khalīl ibn Ahmad al-Farāhidī and so on. Although, There were five major schools of Arabic grammar namely: al-Madhhab al-Basra, al-Madhhab al- Küfa, alMadhhab al-Bagdād, al-Madhhab al- Andalusī and al-Madhhab al-Misrī but this paper, mainly focuses on the two prominent schools - Basran and Küfan. It analyses the conflict of theory in Arabic grammar on some topics and other terms, grammatical debates between notable scholars of the two schools with their divergent opinions. The discussion ends with the justification of analogical deduction employed by the two schools in their analysis as a commendable exercise.
\end{abstract}

Keywords: Hadith, Quran, Arabic grammar

\section{Introduction}

A lot had been written on the contributions of the Qur'ān to the evolution of Arabic Grammar, but few of them focused on the effect of prophetic tradition on the study. This paper, therefore, focuses on semantic connotation of the following ahädith : A non-Arab committed grammatical flaws and prophet said:

$$
\text { إرشدو ا أخاكم فإنّه قد ضلّ }
$$


Meaning:

“ Guide your brother, he has gone astray"

He also said:

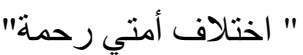

Meaning:

"Divergent opinion of my followers is a blessing"

These sayings of the prophet led to the evolution of Arabic grammatical studies and the establishment of its schools that enriched Arabic grammar (Shawqī,Dayf ,1992:13). Arabic language is one of the major and popular languages for the richness of its vocabulary and fullness of its literature.

As to the vocabulary, any Arabic dictionary shows the wealth of the Arabic tongue in root-words; and any grammar sets forth the almost endless derivative words that can be built from the noun and the verb. Butros Bustani -a lexicographer, put it at the range of 7,000 to 13,000 roots, and the derivatives from 80,000 to 120,000 . As for the literature, the number and importance of the extant works in the Arabic language, on almost every branch of human knowledge, as well as the collection of poems and "belles letters", are so great that one is bewildered by a mere reference to the lists (or fihrists) of the authors and the titles of the books ( Al- Șinjirji, Mustapha Abdul- Azeez ,1986 : 317- 318 ).

Arabic, not unlike other languages, has a rich history. Although, Arabic prescriptive rules have relatively been stable for the reason that Arabs looked at change in the Arabic language as a sort of corruption, bearing in mind the powerful link that exists between this language of the Qur'ān and Islam coupled with the pre-Islamic heritage.

The emergence of Arabic grammar holds its firm root due to the rapid expansion of Islam during the period of the Prophet Muhammad, the four orthodox caliphs and the reign of the Umayyad caliphs when the Muslim territories reached Afganistan and Saragossa (Spain) (Shawqī, Dayf 1992:24). In this sense, the emergence of Arabic grammar is partially a political decision meant to teach the conquered non-Arabs the language of the Qur'an. As a result, non-Arabs learned Arabic as a Lingua Franca to facilitate communication among different "Islamized" countries. It is important to note that most of the early Grammarians such as Abu l-Aswad Addu'alī, Sibawayh and many others were not Arabs by origin. This emphasizes the real concerns of non-Arab grammarians to understand Arabic, to introduce and spread it to their people. (Abdul-Rahman bn Ishaq wa 'Abdul Salam Harūn ,1983: 9).

\section{The Grammarians’ Contribution to the Development of Arabic Grammar}

A number of grammarians, from the emergence of Arabic grammar till now, have contributed to its development. The first grammarian said to 
have contributed to Arabic grammar was Abul-Aswad Addu'alī (d.69 A.H) who was regarded as the pioneer scholar of Arabic grammar. Although, some scholars attributed the glory of pioneering to Seyyid 'Ali b. Abī Talib whose regime was full of unrest due to challenges faced from Umayyad family (Shawqī, Dayf, 1992:31). There was no iota of doubt that he (Abul-Aswad) was the first grammarian to use coloured dots above, below and next to a letter to indicate the three short vowels of the Arabic language (Shawqī, Dayf 1992:13). This contribution was very significant to the Arabic language for the Arabs who wanted to protect the Qur'ân specifically from being adulterated. In fact, this desire was the result of a real concern and consciousness of the Arabs to maintain their language. By the same token, al-Khalīl ibn Ahmad al-Farāhidī was one of the most important philologists of the Basran School. His contribution to Arabic grammar was very significant as he came up with the current standard for the vowel marks in the Arabic Script. Another major contribution of the scholar, was the production of the first Dictionary of the Arabic language namely Kitāb alAyn.

In sum, Arabic grammar, not like other grammars of other living languages, has been undergoing a process of development. Actually, Arabic grammar benefited a lot from the previous findings of the preceding traditional approaches: from the ninth century, a large heritage of new philosophical ideas had been important both from the Greek and the Alexandrian language. At the same time, Arabic grammar was special because of its own environment which was wholly affected by Islam as a predominant religion, by the geographical situation of the Arabic Peninsula, and by the expansion of Muslim territories. Nowadays, Grammar of the Arabic dialects offer a fertile field for the linguist to investigate, in the light of the relatively new linguistic theories which themselves find their roots in the traditional approaches to language study.

\section{Schools of Arabic Grammar}

There were five major schools of Arabic grammar namely; alMadhhab al-Basra, al-Madhhab al- Küfa, al-Madhhab al-Bagdād, alMadhhab al - Andalusī and al-Madhhab al- Misrī (Ahmed, 2011:4). The modern Scholars did not stop conducting researches on the opinions of all these schools of grammar. Either by examining and reviewing the stand of each scholar of these schools on a matter, or giving new trends to the studies as we have Majma'ul-Luggah in Cairo which sees to the refinement of Arabic Language in the recent time. This paper mainly focuses on the two prominent schools - Basran and Küfan. It is from these two schools other established theirs and most of them were disciples of notable scholars of 
these schools or supporters of an opinion of a school during any literary debate.

\section{Basra And Kufah}

Basra was founded as a military encampment by the second caliph, 'Umar bin al-Khattāb, in 638 C.E. about 8 miles $(13 \mathrm{~km})$ from the modern town of Al-Zubayr, Iraq. Its proximity to the Persian Gulf and easy access to both the Tigris and Euphrates rivers and the eastern frontiers encourages its grown into a real city, despite the harsh climate and the difficulty of supplying the camp with drinking water. The first architecturally significant mosque in Islam was constructed there in 665 C.E. Basra has been, however, a brilliant cultural centre in its own right throughout the $8^{\text {th }}$ and into $9^{\text {th }}$ century. It was the home of noted Arab grammarians, poets, prose writers, and literary and religious scholars. Islamic mysticism was first introduced to Basra by al-Hasan al-Basrī, and the theological school of the Mu'tazilah was developed there. Basra is perhaps best known to westerners as the city from which Sinbad set out in "The Thousand and One Nights". (www.dhifaaf.com ,18 August, 2014)

In 655 C.E, the Muslims of Kūfah became the first to support the claims of 'Alī, son-in-law of the prophet Muhammad, against the caliph 'Uthmān; Kūfah subsequently served as 'Alī's capital (656 - 661 C.E). Throughout Umayyad rule Kūfah remained a constant source of unrest. In 683 C.E, in the civil war following the death of the caliph Yazīd I, it recognized as caliph 'Abdullah ibn az-Zubayr; then in 685 C.E, it violently resisted the Shi'ite doctrine forced on it by al-Mukhtar ibn Abū 'Ubayd atThaqafi. Occupied by the 'Abbasids in 749 C.E, the city was maintained as an administrative capital for some years, until the founding of Baghdad. After being sacked by the Qarmatians in 924 - 925, 927 and 937 C.E, Kūfah declined steadily and was almost deserted in the $14^{\text {th }}$ century when it was visited by the geographer Ibn Battutah. In its prime in the $2^{\text {nd }}$ and $3^{\text {rd }}$ Muslim centuries, Kufah, along with Basrah, was a centre for the study of Arabic grammar, philosophy, literary criticism and belles lettres.

Historically, Arabic grammar had experienced a lot of evolution from generation to generation, city to city and individual to individual. The above quoted Hadith opened the eyes of the scholars to research further on how to widen the scope of Arabic grammar in consonance with the word of the prophet: “Divergent opinions of my followers on a matter is a blessing”. The emergence of Arabic schools grammar evaluated the diverse of opinion of notable scholars, this conflict of idea which in turn led to un-imaginable development in the grammar of Arabic language.

The Basrans, being the originator of Arabic grammar and the teacher of all other subsequent schools, in no little measure laid a very important and 
comprehensive foundation for Arabic grammar. The Kufans, despite coming behind the Basrans adopted a more advanced form سماعى (analogy) because instead of restricting themselves to the town where only the standard Arabic is spoken they explored villages in order to identify the dialectical differences for their justification on their grammatical submission. They equally paid special attention to the poetic lines of the Jahiliyyah era to prove so many of their grammatical positions.

\section{Emergence Of Kūfan School}

The Basran school had been in existence for one hundred years before the emergence of the Kufān school of thought. This is one of the facts that, the Kufan scholars at this period were busy with other fields like fiqh, hadīth, Qur'ānic recitation, literature and poetry. This accounted for their establishment of Abū Hanifah school of thought in fiqh and three of the seven major reciters, 'Āsim, Hamzat and al-Kisāi'. They were equally preoccupied by the collection of poem at a time when the Basran scholars were laying very solid foundation for analogical deduction and justification in Arabic grammar, theology, philosophy and logic.

The Kufāns cannot but agree with the Basrans for having the honour of doting the Qur'ān and vowelization of Arabic letters and laying a very solid foundation for Arabic grammar and etymology which was crystallized by Ibn Abī-Ishāq ( Shawqī, Dayf ,1992:27).

Kufan School started with the emergence of Abu Ja'far al-Ru'āsī and Mu'adh bn Muslim al-Harr'a, al-Ru'asi took the knowledge of Arabic grammar from prominent Basran scholars like 'Isā bn 'Umar and Abū Āmid al-Allāi', on his return to Kufān he taught al-Kisāi and wrote a book called "al-Faysal" on Arabic grammar. Another Kufan scholar who benefited from the knowledge of grammar and etymology from the Basran scholars is Mu'ādh bn Mu'ādh bn Muslim al-Harā'i. He established etymology in Kūfah and his student was al-Farrāi'.

It must be emphatically said that Kūfan School was established by alKisāi, who was born in Kūfah. He started grammar from Küfan scholars like Abu Ja'far al-Ru'āsī and Mu'ādh bn Muslim al-Harā'i. He later travelled to Basrah where he met and learnt from al-Khalīl bn Ahmad al-Farāhidī. He moved from one village to another in Basrah in order to perfect his knowledge in Arabic grammar. It was reported that he paid 50 Dirham to Abu al-Hassan al-Akhfash in order to be taught the book of Sibawayh (الكتاب). Al-Farrai, his prominent student, equally assisted in laying solid foundation for the establishment of Kufans school. Tha'alb equally contributed immensely to the development and popularization of the Kufan School. 
Infact, the three most popular of the Kufan scholars are: al-Kisai, alFarrai and Tha'lab. Though, the Basran scholars had emerged before the Kufans, they laid very good foundation for the Kufans and equally taught them Arabic grammar but it must be said that the emergence of the Kufan schools of thought brought a lot of competitions, conflicts, controversies which consequently led to a drastic development in Arabic grammar (Ahmed, 2011:109).

\section{The conflict of theory in arabic grammar}

There have been debates and discussions on linguistics argumentations used by both schools Basra and Kūfa in order to impose their principles in modification of Arabic Grammar. This kind of scenario contributes some negatives and positives views among the scholars claimed that Basrah and Küfah were the two cities which permanently rivaled each other. In principle, Basrah and Küfah do evidence two differing linguistic and grammatical approaches. The school of Basra was more philosophically inclined when formulating the rules of Arabic grammar while the school of Kufah extended its rules on evidence found in classical texts. Although, Basra applied more analogy does not mean that Kufan scholars did not, they also refer to the already existing linguistic corpus in the classical texts. In order to re-evaluate the above discussion, bellow is examples of grammatical debates between notables scholars سييويه و الكسائي that enrich our grammatical exposition.

$$
\text { مناظر ات اللغوية بين سيبويه و الكسائي }
$$

\section{Grammatical debates between notable scholars of the two schools}

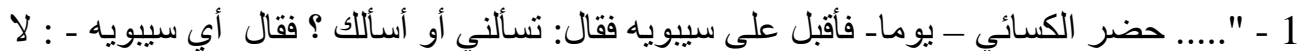

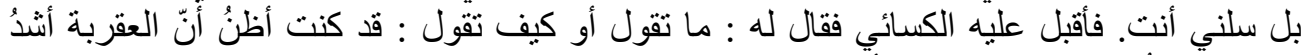

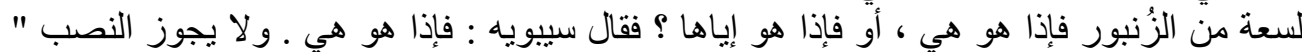

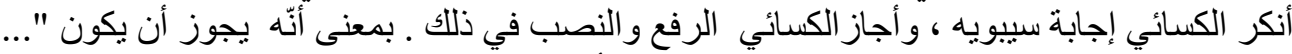

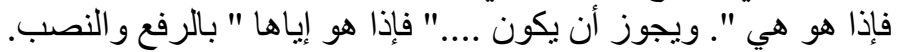

Meaning:

Al-Kisai in one occasion met Al- Sibawayh and asked during a discourse; Do you ask me or I ask you (on a grammatical debate) He replied; ask . He (Al-Kisai) said: What is your grammatical position on this sentence

Sibawayh replied;

$$
\text { أظنُ أنّ العقربة أشنُ لسعة من الزُنبور فإذا هو هي ، أو فإذا هو إياها ؟ }
$$

But it can also be in accusative case as well as nominative that is :

$$
\text { أظنُ أنّ العقربة أشندُ لسعة من الزُنبور فإذا هو هي ، أو فإذا هو إياها ؟ }
$$

أفئ Another notable grammarian commented on this incident;

$$
\text { "قد اختلفتما و أنتما رئيسا بلديكما " ـ و هذه الاختلاف رحمة ” }
$$


Meaning: "Two of you differ in your opinion and you are the leaders of your town but the divergence is also a blessing."

This enlightened learners of grammar not to ignorantly wrong others since the native speakers allow both cases. This blessing really assisted the generation to know that whoever chose any of the position is on the right path:

: " فإذا هو هي " على رأي سييويه ، وهو الصواب ، ومن يقول: "فإذا هو إياها "على رأي الكسائي

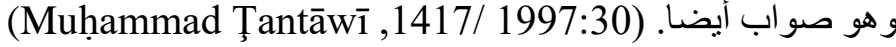

2- Another discourse between Sibawayh and Kisāī ;

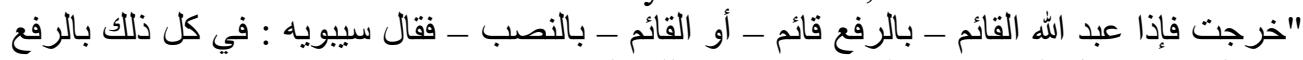

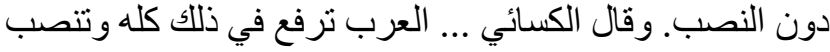

(Muhammad Ţantāwī ,1417/ 1997:40).

The discussion centred on the legality of both accusative and nominative cases.

3- Another discourse between Kisāī and al- Asmaī ;

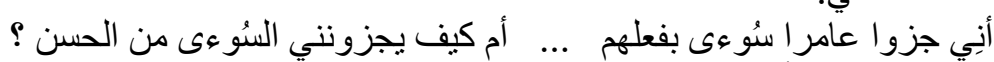

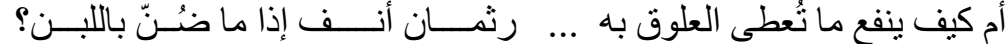

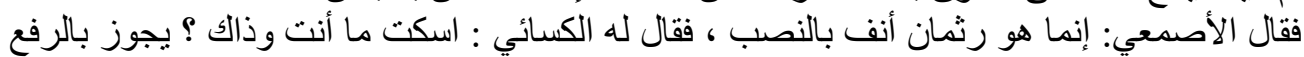

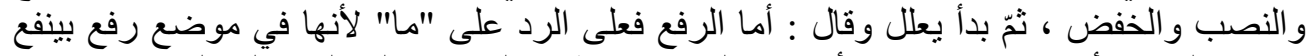

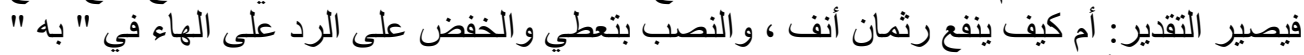

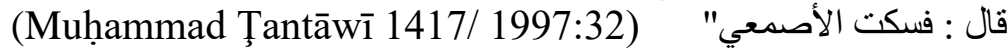

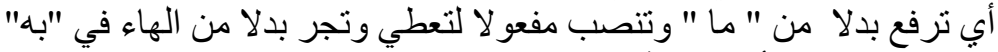

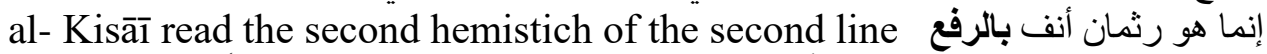
but al- Asmaî́ wronged him and said إنما هو رثمان أنف بالنصب al- Kisāî quickly reacted by saying: keep quite, it is grammatically permissible to be in the three cases that is ; Nominative, Accussative and Genetive.

\section{Divergent Opinions between Basran and Kufan Schools on some Topics}

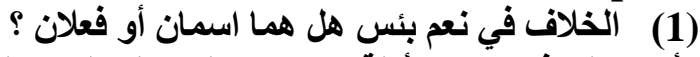

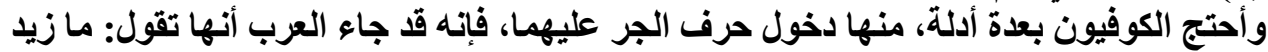

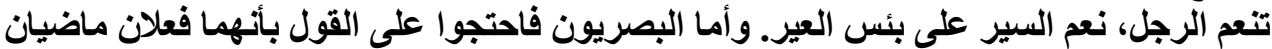

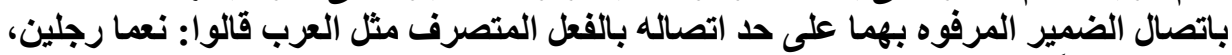

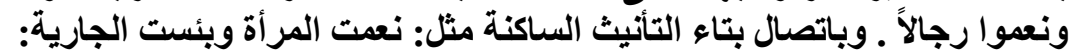

(www.majles.aluggah. Net/10936: 20 feb., 2015).

The Kufans opined that since نعم بئس accepts genitive case they are nouns,

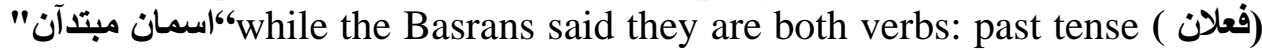

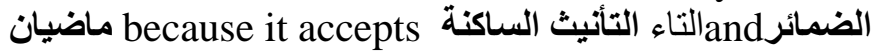

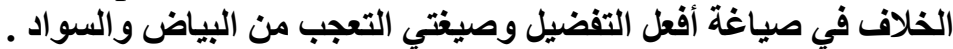

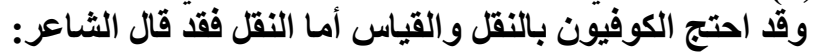

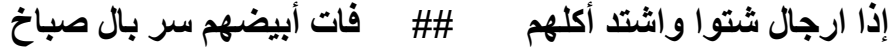




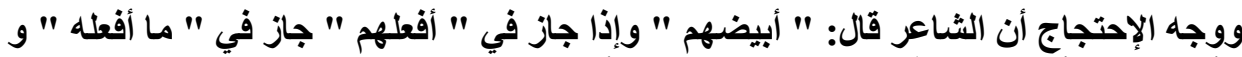

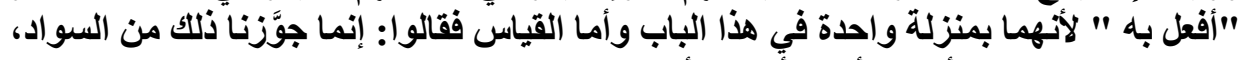

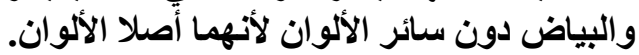

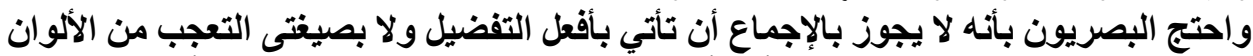

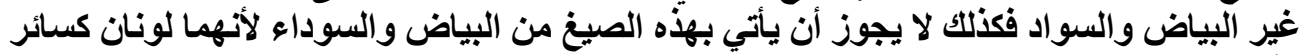
الألوان.

The Kufans opined that "ما أفعل"can be used in expressing

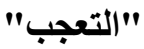
(Exclamation) in colour white and black alone, e.g.

$$
\text { " هذا الثوب ما أبيضه ; الشعر ما أسوده }
$$

The Kufans also evidenced with this poem:

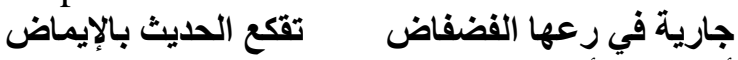

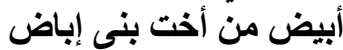

But the Basrans insisted that it is not applicable even to colours أفعل التفضيل وصيغتى التعجب والبياض because, white and black are part of colours من السواد.

The Basran disagreed with the position of the Kufans because, evidences used by the Kufans to justify their position are mostly from the poem of the poets who could have made a grammatical blunder since Basrans many at times based their opinion on philosophy and logic . Whoever uses any of the scholastic stands has widened his knowledge but majority of scholars stick to Basran submission. (Muhammad Țantāwī, 1417/ 1997:30).

Other Terms with Divergent Opinions between Basran and Kufan Schools.

\begin{tabular}{|c|c|}
\hline BASRAN & KUFAN \\
\hline ضمير & مكني \\
\hline ضمير الفصل & العماد \\
\hline البدل & الترجمة \\
\hline النفي & الجحد \\
\hline اسم الفاعل & فعل الدائم \\
\hline الجر & الخفص \\
\hline التمييز & التفسير \\
\hline صفة & نعت \\
\hline
\end{tabular}

\section{Conclusion}

The role of Hadith of the Prophet in encouraging scholars to have indepth study on all the fields cannot be over emphasized. Their main objective in doing this is gearing towards understanding the message of the Qur'ān which is rewardable exercise. The emergence of the schools of 
grammar were given attention with semantic interpretation of the Hadith by notable and pioneer scholars of these schools. Literary discussions examined appeared as rivalry between the Basran and Kufan Schools but It must be emphatically said that, it is advantageous to the richness of Arabic Grammar as a field of study. The analogical deduction employed by the two schools in their analysis and justification is commendable.

\section{References:}

Abdul-Rahman bn Isḥaq wa 'Abdul Salam Harūn (1983):Majālisul'Ulamā' Misra : Maktabatul-Khanij̄̄

Ahmed, L (2011): Al Mustalih an -Naḥwi baynal- basriyyin wal kufiyyīn.: Sharja

Al- Shinjirji, Mustapha Abdul- Azeez (1986): al-Madhāhib an- Nahwwiyyah fi Daw 'id-Dirāsāt al-Lughawiyyah al-Hadīthah Jeddah: al-Faysaliyyah Ibrahim Samira'I,( n.d): al-Madrasat al-Nahwiyyah; waqū‘ wa Ustaratun Cairo: Dāru l-fikr.

Muḥammad Țantāwī (1417/ 1997): Nașa’tul- Naḥwi wa Tārikh’AṣhurulNuhāt,Raja'hu wa 'allaqa 'alayhi Sa'ìd Muhammad al-Lihām Al- Taba 'atul-'Ulā Misr: Maktabatul- 'Alam

Shawqī, Dayf (1992): al-Madārisu al-Naḥwiyyah, Cairo: Dārul-Ma 'ārif 